\title{
М'ЯСО-САЛЬНА ПРОДУКТИВНІСТЬ І ФІЗИКО-ХІМІЧНІ ВЛАСТИВОСТІ М'ЯСА СВИНЕЙ РІЗНИХ ГЕНОТИПІВ
}

\section{Рецензент - доктор ветеринарних наук, професор М. В. Чорний}

Статтю присвячено порівняльному вивченню відгодівельних і м'ясних якостей свиней різного напряму продуктивності: великої білої породи (універсальної), породи ландрас та їх помісних нащзадків в аналогічних умовах годівлі й утримання. Узагальнено результати дослідження м'ясної продуктивності молодняку свиней різних генотипів. Отримано та проаналізовано додаткові дані м'ясо-сальної продуктивності та фізико-хімічних властивостям м'яса свиней. За результатами досліджень встановлено позитивну обумовленість продуктивних якостей свиней залежно від генотипу та проведено теоретичне обтрунтування прогнозування показників продуктивності.

Ключові слова: свині, фізико-хімічні властивості м'яса, м'ясна продуктивність, генотип.

Постановка проблеми. Технології вирощування свиней в умовах сучасної України пов'язані зі збереженістю та підвищенням продуктивності свинопоголів'я 3 найменшими витратами, так як у результаті інтенсивної селекції за репродуктивними якостями погіршуються якісні показники м'ясної продукції. Впровадження й розробка нових прийомів ефективного використання перспективного генофонду свиней та раннє прогнозування продуктивності допоможуть забезпечити іï підвищення в племінних і товарних господарствах східного регіону України.

Відгодівельні та м'ясні якості свиней різних генотипів залежать від типу конституції свиней. Найвищі показники середньодобового приросту спостерігаються у помісних тварин, але більшу живу масу мають поросята м'ясного напряму продуктивності. Високі показники енергії росту i низькі затрати корму відмічені у поросят змішаного генотипу [1].

Аналіз останніх досліджень і публікацій, у яких започатковано розв'язання проблеми. У сучасних літературних джерелах зустрічається багато інформації, присвяченої впливу генотипу на м'ясні якості свиней [4]. М'язова і жирова тканини впливають на смак та аромат м'яса, його якість залежить від хімічного складу, фізичних якостей і показників біологічної повноцінності структури м'язової тканин, а також безпосеред- ньо від породи, віку, статі, годівлі та інших чинників. Тварини різних напрямів продуктивності в однаковому віковому періоді дають свинину різного морфологічного складу та якості. За вмістом протеїну в м'ясі кращими були породи велика біла та ландрас $(21,1 ; 19,8 \%)$. Підвищена кількість жиру спостерігалась у великої білої породи української селекції та їі інших поєднань. Визначено позитивний корелятивний зв'язок між м'ясо-сальними якостями свиней та їх генотипом та виявлені кращі породні поєднання тварин, які забезпечують кращий гетерозисний ефект за продуктивними якостями [7]. Багато уваги приділяється показникам свіжості та якості м'яса залежно від продуктивного напрямку свинарства, зокрема фізико-хімічним властивостям м'яса і сала свинок різних генотипів. На основі багатьох праць встановлено також відмінності за енергією росту, виходом продукції, затратами кормів у дослідних свиней різних порід [3].

Для можливості прогнозування відгодівельних якостей свиней на ранніх етапах розвитку виникає необхідність у більш розгорнутому й досконалому аналізі цих якостей у різних варіантах генотипів, що обумовлено різноманітністю генофонду в усіх регіонах країни.

На даному етапі розвитку методик досліджень маємо можливість порівнювати отримані показники м'ясо-сальної продуктивності та фізикохімічних властивостей м'яса свиней на сучасному рівні й одержувати високодостовірні результати, які відповідають вимогам європейських стандартів [8].

Мета дослідження: отримати дані щодо показників м'ясо-сальної продуктивності свиней генотипів, поширених на сході України, розрахувати достовірність отриманих результатів згідно зі стандартами ISO.

Завдання дослідження: 3'ясувати вплив генотипу на кількісні показники відгодівельних якостей свиней та можливість їх використання для прогнозування продуктивності тварин різних генотипів на ранніх етапах розвитку. 


\section{СТОРІНКА МОЛОДОГО ВЧЕНОГО}

Методи і методика досліджень. Досліди проводилися на базі двох господарств сходу України: ПП «Агропрогрес» і ПАТ «Насіннєве» Кегичівського району Харківської області. Було сформовано шість груп нащадків від свиноматок різних генотипів: I, II, III групи - ПП «Агропрогрес» IV, V, VI - ПАТ «Насіннєве».

Матеріалом для досліджень стали свині порід велика біла і ландрас та їх чистопородні й помісні нащадки. В обох господарствах за принципом аналогів було сформовано по три групи свиней, по 10 голів $(\mathrm{n}=10)$ у кожній: I, IV - велика біла порода; II, V - порода ландрас; III, VI велика біла.

Свині I, IV груп запліднювалися кнурами породи велика біла, а свині II,V і III, VI - кнурами породи ландрас. Поросних свиноматок утримували у групових станках у відповідності до технології. За три дні до очікуваного опоросу переводили в індивідуальні станки свинарникаматочника. Запліднення свиноматок в обох господарствах проводилось штучно.

Відбір проводили після першого опоросу 3 урахуванням віку, типу і продуктивності, згідно середніх параметрів породи.

Для вивчення відгодівельних якостей та продуктивних характеристик за чистопородного розведення та схрещування досліди проводилися на молодняку свиней великої білої та породи ландрас від I, IV i II,V груп свиноматок і на помісних свинях цих же порід від свиноматок III,VI груп у разі досягнення ними ваги 100 кілограмів.

Характеризуючи породну належність свиней, використовували наступні умовні значення: ВБ свині великої білої породи, Л - свині породи ландрас, S ВБ+S Л - помісні свині обох порід. (табл. 1).

У тварин - за загальноприйнятими зоотехнічними методами - визначали масу за постановки на відгодівлю, масу в час зняття з відгодівлі, середньодобовий приріст на відгодівлі, абсолютний приріст, відносний приріст, затрати корму на 1 кг приросту, співвідношення тканин у туші (м'яса, сала, кісток).

Фізико-хімічними методами в м'ясі визначали вологість, кислотність, кількість протеїну, жиру та золи.

Обробку експериментальних даних проводили методом варіаційної статистики за М. О. Плохинським [2].

Результати досліджень. Для проведення контрольної відгодівлі було відібрано молодняк від кожної дослідної групи свиноматок, сформовано групи з чистопородного і помісного молодняку. Тварини утримувались в однакових умовах. Відгодівельні якості піддослідних свиней різних генотипів наведені в таблиці 2.

\section{1. Схема досліджень}

\begin{tabular}{|c|c|c|c|c|}
\hline \multirow[b]{2}{*}{ Групи } & \multirow[b]{2}{*}{ Господарство } & \multicolumn{3}{|c|}{ Породна належність } \\
\hline & & свиноматок & кнурів & $\begin{array}{c}\text { піддослідного } \\
\text { молодняку }\end{array}$ \\
\hline I & \multirow{3}{*}{$\begin{array}{c}\text { ПП } \\
\text { «Агропрогрес» }\end{array}$} & ВБ & ВБ & ВБ \\
\hline II & & Л & Л & Л \\
\hline III & & ВБ & Л & $\mathrm{S}$ ВБ+S Л \\
\hline IV & \multirow{3}{*}{ ПАТ «Насіннєве» } & ВБ & ВБ & ВБ \\
\hline $\mathrm{V}$ & & Л & Л & Л \\
\hline VI & & ВБ & Л & $\mathrm{S} \mathrm{BБ+S} \mathrm{Л}$ \\
\hline
\end{tabular}

\section{2. Відгодівельні якості піддослідного молодняку, $\mathrm{M \pm m}$}

\begin{tabular}{|c|c|c|c|c|c|c|}
\hline \multirow{2}{*}{ 志 } & $\begin{array}{c}\text { Маса при по- } \\
\text { становці на від- } \\
\text { годівлю, кг }\end{array}$ & \begin{tabular}{c} 
Маса при \\
зівті з відго- \\
\cline { 2 - 6 }
\end{tabular} & $\begin{array}{c}\text { Середньодобо- } \\
\text { вий приріст, г }\end{array}$ & $\begin{array}{c}\text { Абсолютний } \\
\text { приріст, кг }\end{array}$ & $\begin{array}{c}\text { Відносний } \\
\text { приріст, \% }\end{array}$ & $\begin{array}{c}\text { Затрати корму } \\
\text { на 1 кг прирос- } \\
\text { ту, к. о. }\end{array}$ \\
\hline I & $17,4 \pm 0,03$ & $101,2 \pm 0,19$ & $454,7 \pm 0,86$ & $100,1 \pm 0,2$ & $48,9 \pm 0,001$ & $4,16 \pm 0,01$ \\
\hline II & $18,6 \pm 0,04$ & $100,8 \pm 0,22$ & $452,7 \pm 0,98$ & $99,6 \pm 0,2$ & $48,8 \pm 0,001$ & $4,01 \pm 0,01$ \\
\hline III & $17,5 \pm 0,03$ & $101,6 \pm 0,27$ & $456,1 \pm 1,21$ & $100,4 \pm 0,3$ & $48,9 \pm 0,001$ & $4,08 \pm 0,01$ \\
\hline IV & $17,5 \pm 0,03$ & $100,8 \pm 0,22$ & $452,9 \pm 0,98$ & $99,7 \pm 0,2$ & $48,9 \pm 0,001$ & $4,24 \pm 0,01$ \\
\hline V & $18,6 \pm 0,04$ & $100,4 \pm 0,09$ & $450,9 \pm 0,43$ & $100,0 \pm 0,2$ & $48,8 \pm 0,001$ & $4,18 \pm 0,01$ \\
\hline VI & $17,5 \pm 0,03$ & $101,2 \pm 0,19$ & $454,3 \pm 0,85$ & $99,2 \pm 0,1$ & $48,9 \pm 0,001$ & $4,14 \pm 0,01$ \\
\hline
\end{tabular}




\section{СТОРІНКА МОЛОДОГО ВЧЕНОГО}

Відгодівля проводилася згідно 3 методичними рекомендаціями, за типовими раціонами в господарствах, до живої маси 100 кілограмів. Живої маси 100 кг піддослідні тварини в середньому досягали за 214 днів, за середньодобових приростів 453,65 г і затратах на 1 кг приросту 4,2 кормових одиниці. На відгодівлі помісний молодняк III та VI груп за середньодобовими приростами перевищував чистопородний молодняк породи велика біла та ландрас на $0,31 \%$ і на $0,76 \%$, а в час зняття 3 відгодівлі його маса була незначно, але вищою, ніж у тварин чистопородного генотипу, й складала в середньому 101,19-101,57 кілограмів.

Різниця між I і III, IV і VI групами незначна й не $\epsilon$ достовірною $\mathrm{P}<0,95$, а між II і III $(\mathrm{P} \geq 0,95)$ та

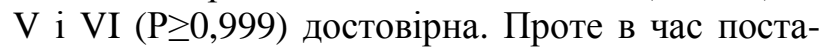
новки на відгодівлю найбільші показники живої маси були у поросят породи ландрас $(18,62-$ 18,63 кг), але за період відгодівлі вони мали низьку інтенсивність росту, що обумовлено їх генотипом. Тому найвищі показники середньодобових приростів спостерігались у помісного молодняку (456,14-454,32 г) з найменшими затратами корму на 1 кг приросту 4,08-4,14 к.о. Рiзниця середньодобових приростів між I і III, IV i VI групами - недостовірна $(\mathrm{P}<0,95)$; між II i III та V i VI - достовірна, зі ступенем вірогідності $\mathrm{P} \geq 0,95$.

Показникам якості та кількості м'яса надається чимало уваги в розробці селекційних програм, спрямованих на розведення тварин, спеціалізованих за м'ясністю. Проте селекція за м'ясністю викликає низку негативних наслідків, пов' язаних iз послабленням природної резистентності, погіршенням якості м'яса та іншим, що викликано не лише паратиповими, але й генотиповими факторами.

Глибоку й об' єктивну інформацію про м'ясосальні якості свиней різних генотипів можна одержати в ході аналізу складу туш.

Морфологічний склад туш залежить від породних особливостей тварин, про що свідчать результати обвалки туш піддослідних свиней різ- них генотипів [5]. Найбільший вихід м'яса мали тварини породи ландрас II та IV групи м'ясного напряму продуктивності; при забої в 100кг 56,9-57,3 \%. Різниця між цими показниками достовірна для всіх дослідних груп Р $\geq 0,999$. Вихід сала був найбільшим у тварин породи велика біла - I групи; вони переважали своїх ровесників II групи на 7,7 \%, III групи на 3,5 \% 3 достовірністю $\mathrm{P} \geq 0,999$. Вихід кісток представників усіх дослідних груп знаходився на рівні 10,9-11,4\%, відрізнявся незначно і був невірогідним $\mathrm{P}<0,95$. Про це свідчать дані отримані в результаті досліджень і наведені в таблиці 3.

В оцінці м'ясних якостей мають значення не лише кількісні показники співвідношення м'яса, сала та кісток, але й їх харчова цінність (якість продукції забою), що в кінцевому підсумку і $\epsilon$ головним критерієм оцінки харчової та господарської цінності свиней.

У результаті інтенсивної селекції на скороспілість спостерігається погіршення якісних показників м'яса [6]. М'ясо свинини відрізняється від інших видів м'яса блідістю, що обумовлено низьким вмістом у ньому міоглобіну (м'язового пігменту) i швидким перетворенням енергетичної речовини (глікогену) в молочну кислоту після забою.

Це впливає також на показник кислотності м'яса (pH), - для якісної свинини він завжди менше 6,0 (у нормі 5,4-5,5), що характеризує м'язи як кислі і знижує їх вологоутримуючу здатність. Внаслідок цього м'ясо набуває грубоволокнистої структури.

Це пояснює перевагу використання свинини в ковбасному виробництві, де існує необхідність утримання значної кількості вологи.

Вивчення фізико-хімічних властивостей м'яса піддослідних груп свиней різних генотипів показало, що всі показники якості м'яса були в межах фізіологічних норм, властивих для даних тварин.

Такі показники як вміст протеїну та жиру в м'ясі, що підтверджено дослідженнями, наведеними в таблиці 4, визначаються породним фактором.

3. Співвідношення тканин у туші, $\mathrm{M \pm m}$

\begin{tabular}{|c|c|c|c|c|c|c|}
\hline \multirow{2}{*}{ Показник } & \multicolumn{5}{|c|}{ Групи } \\
\cline { 2 - 7 } & $\mathrm{I}$ & $\mathrm{II}$ & $\mathrm{III}$ & $\mathrm{IV}$ & $\mathrm{V}$ & VI \\
\cline { 2 - 7 } & $\mathrm{M} \pm \mathrm{m}$ & $\mathrm{M} \pm \mathrm{m}$ & $\mathrm{M} \pm \mathrm{m}$ & $\mathrm{M} \pm \mathrm{m}$ & $\mathrm{M} \pm \mathrm{m}$ & $\mathrm{M} \pm \mathrm{m}$ \\
\hline М'ясо, \% & $55,0 \pm 0,03$ & $57,3 \pm 0,11$ & $56,1 \pm 0,07$ & $55,7 \pm 0,11$ & $56,9 \pm 0,07$ & $56,0 \pm 0,07$ \\
\hline Сало, \% & $33,9 \pm 0,09$ & $31,3 \pm 0,13$ & $32,7 \pm 0,12$ & $33,4 \pm 0,11$ & $31,6 \pm 0,12$ & $32,9 \pm 0,12$ \\
\hline Кістки, \% & $11,1 \pm 0,09$ & $11,4 \pm 0,15$ & $11,3 \pm 0,14$ & $10,9 \pm 0,13$ & $11,6 \pm 0,15$ & $11,1 \pm 0,14$ \\
\hline
\end{tabular}


СТОРІНКА МОЛОДОГО ВЧЕНОГО

4. Фізико-хімічний складм'яса свиней різних генотипів, $M \pm m$

\begin{tabular}{|c|c|c|c|c|c|}
\hline Групи & Кислотність, рН & Вологість, \% & Протеїн, \% & Жир, \% & Зола, \% \\
\hline I & $5,52 \pm 0,003$ & $75,3 \pm 0,02$ & $20,6 \pm 0,003$ & $2,5 \pm 0,020$ & $1,14 \pm 0,002$ \\
\hline II & $5,60 \pm 0,002$ & $75,7 \pm 0,02$ & $20,7 \pm 0,004$ & $2,4 \pm 0,002$ & $1,21 \pm 0,010$ \\
\hline III & $5,51 \pm 0,003$ & $75,5 \pm 0,02$ & $19,9 \pm 0,009$ & $2,6 \pm 0,004$ & $1,15 \pm 0,002$ \\
\hline IV & $5,47 \pm 0,003$ & $75,2 \pm 0,03$ & $20,6 \pm 0,008$ & $2,6 \pm 0,005$ & $1,14 \pm 0,002$ \\
\hline V & $5,54 \pm 0,002$ & $75,7 \pm 0,02$ & $20,8 \pm 0,120$ & $2,5 \pm 0,001$ & $1,18 \pm 0,002$ \\
\hline VI & $5,51 \pm 0,002$ & $75,5 \pm 0,02$ & $19,9 \pm 0,007$ & $2,50 \pm 0,002$ & $1,15 \pm 0,001$ \\
\hline
\end{tabular}

М'ясо свиней відзначалося високим вмістом протеїну, найбільша кількість протеїну виявлена у помісних тварин III, VI групи, - вона коливається в межах 20,7-20,8\%. Це на $0,48 \%$ і на $3,87 \%$ відрізняється від аналогічного показника у ровесників інших чистопородних і помісних груп із достовірною різницею - $\mathrm{P} \geq 0,999$. Найбільша кількість жиру у м'язовій тканині виявлена у помісних тварин III, VI групи. Різниця між цими дослідними показниками достовірна $\mathrm{P} \geq 0,999$. Кількість золи в м'ясі практично не відрізняється в усіх дослідних групах, становлячи 1,14-1,2 \%, i різниця між ними недостовірна $(\mathrm{P}<0,95)$. За наявністю вологи в м'ясі не визначено суттєвих відмінностей між породами свиней в разі забою в 100 кілограмів. Кількість вологи в усіх дослідних групах визначалася на рівні 75,3-75,7\%. Незначні відмінності між групами виявлено й за показником кислотності (pH) м'яса - на рівні

\section{БІБЛІОГРАФІЯ}

1. Акимова А. Продуктивность свиней различных типов конституции // Свиноводство. - 1987. - №8. - C. 2-3.

2. Барановський Д. І. Основи біометрії: навчальний посібник / Д. І. Барановський, С. Б. Данілов. - Х. : СП «Бровін О.В.», 2010. - 90 с.

3. Бірта Г. О. Формування м'ясо-сальної продуктивності різних генотипів свиней залежно від паратипових факторів : Автореф. дис. ... д-ра. с.-г. наук : 06.02.01. - Київ-Чубиньське, 2009. $38 \mathrm{c}$.

4. Бордун О. М. Відгодівельні та м'ясні ознаки свиней різних генотипів при їх чистопородному розведенні та схрещуванні / О. М. Бордун // Bicник Сумського національного університету: Тваринництво. - 2007. - №3. - С. 7-9.

5. Даниленко И. П. Справочник по качеству
5,5-5,55; різниця між дослідними групами несуттєва і недостовірна $(\mathrm{P}<0,95)$, знаходиться в межах фізіологічних норм.

Поєднання тварин різних генотипів суттєво не вплинуло на погіршення чи поліпшення показників якості м'яса, хоча певні відмінності між породами спостерігалися.

\section{Висновки:}

1. Значний потенціал біологічних можливостей помісних тварин дає змогу отримувати високоякісне поголів'я свиней, яке може бути рекомендоване для утримання в товарних господарствах.

2. Відгодівельні та м'ясні якості свиней залежать від генотипу й продуктивного типу породи.

3. Показники відгодівельних і м'ясних якостей можуть бути використані для прогнозування продуктивності свиней.

продуктов животноводства. / И. П. Даниленко, Л. В. Минитюк, И. И. Шуст. - К. : Урожай, 1988. $98 \mathrm{c}$.

6. Карапуз B. В. Відгодівельні та м'ясні ознаки свиней різних генотипів при їх чистопородному розведенні та міжпородному схрещуванні / В. В. Карапуз // Вісник аграрної науки Причорномор'я. - 2010. - №4. - С. 192-197.

7. Онищенко $A$. Фізико-хімічний склад м'яса у свиней різних генотипів / А. Онищенко // Тваринництво України. - 2006. - №7 - С. 17-19.

8. ISO 3100-1 Meat and meat products - Sampling and preparation of test samples - Part 1: Sampling (М'ясо та м'ясопродукти. Відбирання зразків і підготовка зразків до вимірювання. - Ч. 1. «Відбирання зразків»). 